Ankara Sağlık Hizmetleri Dergisi,

Cilt 11, Sayı 1, 2012

\title{
Olgu Sunumu: Akut Lenfoblastik Lösemi (ALL)’ li Çocuğun Evde Egzersiz Programının Sürdürülmesi ${ }^{1}$
}

\author{
Meltem KÜRTÜNCÜ TANIR ve Sema KUĞUOĞLU²

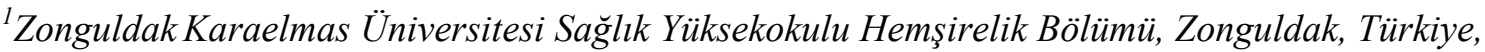 \\ meltemkurtuncu@yahoo.com \\ ${ }^{2}$ Marmara Üniversitesi, Sağlık Bilimleri Fakültesi, Hemşirelik Bölümü, Emekli Öğretim Üyesi, \\ Istanbul, Türkiye,
}

\begin{abstract}
Özet
Akut Lenfoblastik Lösemili (ALL) çocuklarda vücut fonksiyon bozuklukları ve aktivite sınırlılıkları görülür. Yoğun tedaviye bağlı olarak bu çocuklarda \%15-29 oranında kemik mineral yoğunluğunda azalma olduğu, yorgunluk ve enerji eksikliğine bağlı olarak fiziksel aktivite azalmasının osteoporoz riskini arttırdığı belirtilmektedir. Bu makalede; üç ay boyunca pediatri hemşiresi tarafindan yapılan haftalık ev ziyaretleri ile desteklenen fiziksel egzersiz sonucunda, ebeveynleri B'nin evde egzersizlerini düzenli olarak yaptığını, günlük aktivitelerini yerine getirmede şikâyetçi olmadığını belirtmişlerdir. B'de yorgunluk ve halsizliğinin azaldığını, egzersizleri yaptığında kendisini daha iyi hissettiğini belirtmiştir.
\end{abstract}

Anahtar Kelimeler: Akut Lenfoblastik Lösemi, Hemşirelik bakımı, Egzersiz, Gordon’un fonksiyonel sağlık örüntüleri

\section{Case Presentation: Exercise Program At Home Of Child With Acute Lymfhoblastic Leukemia}

\begin{abstract}
Children with Acute Lymphoblastic Leukemia (ALL) display body function disorders and are restricted in their activity. Because of the intensive treatment received, these children suffer a 15$29 \%$ decrease in bone mineral density. It is stated that diminished physical activity related to fatigue and energy loss increases the risk of osteoporosis. This article at the end of the 3 month period of physical exercises at home, which was monitored by a visiting pediatric nurse, parents of B said that he exercised regularly and did not complain of difficulty in going about his daily activities. They reported that B's fatigue and feelings of weakness had diminished and that he felt better when he performed his exercises.
\end{abstract}

Keywords: Acute Lymphoblastic Leukemia, Nursing care, Exercise, Gordon's functional health patterns

\footnotetext{
${ }^{1}$ Araştırmanın yapılacağı Üniversite Hastanesi Etik Kurulundan ve Hematoloji/Onkoloji bölümlerinden uygulama izni alındı. Olgu olarak ele alınan çocuk ve ebeveynine çalışmanın amacı, planı ve yararları açıklanarak Hasta Bilgilendirme Formu imzalatıldı. Bu açıklamalar doğrultusunda çalışmaya katılmayı kabul eden çocuk ve ebeveynine Hasta Onam Formu imzalatılarak uygulamaya başlanmıştır.
} 


\section{Giriş}

Akut lenfoblastik lösemi (ALL) çocukluk çağlarında en sık görülen neoplastik hastalıktır ve çocuklarda görülen neoplazmların \%40'ını oluşturur. Normal kemik iliğinde eritroid, miyeloid ve megakaryositer serilerin ana, ara ve olgun hücreleri, periferik kanda da yine bu serilerin olgun şekilleri bulunur. ALL'de ise normal kemik iliği hücrelerinin yerini blast adı verilen farklılaşmamış ana hücreler almıştır. Blastlar, kemik iliğinden periferik kana ve diğer sistemlere yayılarak ALL'ye özgü ağır klinik tablonun oluşmasına yol açarlar (Neyzi ve Ertuğrul 2002).

Çocukluk çağı kanserlerinin \% 25-30’unu lösemiler oluşturur (Pui ve Evans 2006). Amerika Birleşik Devletleri'nde 15 yaş altında tanı alan kanserlerin \%23'ünü ALL'nin oluşturduğu bildirilmektedir. Gelişmiş ülkelerde akut lösemilerin \% 83'ünü ALL, \% 17sini AML oluşturmakta olup, insidansta bölgesel farklılıklar görülebilir (http://seer.cancer.gov/publications/childhood/ leukemia.pdf, Erişim:15.11.2011).

Birçok çalışma, ALL'nin uzun dönem sonuçlarını sekonder malignensiler, kardiyak anomaliler, nefrit, pulmoner disfonksiyon ve hipertansiyona odaklamıştır (Edgar et al., 2009, Hockenberry-Eaton et al., 2002; Shaw, 2009). İlave olarak; öğrenme bozuklukları, avasküler nekroz, osteoporoz, obesite, ayak bileği hareket alanında azalma, kaba ve ince motor hareketlerinde azalma saptanmıştır (Barr ve Sala, 2008; Bhatia ve Constine, 2009; Gocha, Chiarello, Lange, 2003; Hartman et al., 2008; Mattano et al., 2000; Reinders-Messelink et al., 1999; San Juan et al., 2008; White et al., 2005).

Aynı zamanda, kısa dönemde ALL'li çocuklarda vücut fonksiyon bozuklukları ve aktivite sınırlılıkları görülür. Yapılan bir çalışmada, Vincristine alan çocuklarda tedavinin başlamasını takiben ilk ay'da periferal nöropati geliştiği saptanmıştır. Periferal nöropatinin ilk belirtisi de derin tendon reflekslerinde görülen azalmadır (Hartman et al., 2006). Diğer semptomlar parastezi, ağrı, kas krampları, kas zayıflı̆̆ı, ayak bileği hareket alanında azalma, konstipasyondur (Hartman et al., 2008; Wright, Halton, Barr, 1999; Wright, Hanna, Halton, Barr, 2003). Gocha ve arkadaşlarının (2003) yaptığı bir çalışmada, ALL'li çocuklarda kemoterapi tedavisine başladıktan sonra ilk y1l içinde fonksiyonel mobilitede, bacakları uzatma gücünde ve ayak bileği dorsifleksiyon gücünde azalmanın olduğunu saptamışlardır.

ALL'li çocuklarda hareket alanları, güç ve dayanıklılıkla ilgili sorunların görüldüğü bilinmesine rağmen, bu çocuklarda egzersizin etkileri ile ilgili çok az çalışma bulunmaktadır. Wright ve arkadaşları (1999), ALL tanısı ile tedavi edilen çocuklar üzerinde aktif ve pasif dorsifleksiyon alt ekstremite egzersizleri eklemlerin hareket genişliği (ROM) ile yapılan fizik tedavinin etkisini araştırmış ve sonuçta ayak bileği dorsifleksiyon ROM'nun, kemoterapi tedavisinin tamamlanmasını takiben 6 ayda önemli derecede azaldığını belirlemişlerdir. San Juan ve arkadaşlarının (2007) ALL'li çocuklarla egzersizin etkilerini inceledikleri çalışmada, egzersiz sonrası çocukların fonksiyonel hareketlilik, aerobik egzersiz ve dayanıklılıkta önemli artışın olduğu belirlenmiştir.

Çocuklar ve adölesanlara yönelik çok sınırlı çalışmalar olmasına rağmen, pediatrik yaş grubunda egzersiz girişimlerinden beklenen sonuçlar erişkinlerden farklı olabilir. Yapılan bir çalışmada, lenfoblastik lösemi için başarılı bir şekilde tedavi edilen 13-14 yaşlarında üç çocukta, 12 haftalık egzersiz programının fiziksel ve psikolojik etkileri araştırılmıştır. Sonuç olarak, öncelikle $\mathrm{VO}_{2}$ max'ta (maksimal oksijen tüketimi) düşüş, aşırı tartı alımı, bütün psikolojik testlerin yüksek anksiyete skorlarında iyileşme saptanmıştır. Egzersiz programlarının kanserli çocukların, tedavi sonrası yönetiminde yararlı olduğu önerilmektedir (Bar-Or and Rowland 2004). Başka bir çalışmada, iyileşmiş en az bir yıldır kemoterapi ve radyasyon tedavisi almayan puberte sonrası kanserli çocuklar 
(n:10) üzerinde, haftada iki kez, hastanede yapılan aerobik egzersizin etkisi değerlendirilmiştir. Bu programla koşu bandına dayanma gücü \%13 arttırılmış ve $\mathrm{VO}_{2} \max \% 8$ iyileşmiş, fakat değerlerin normaller için tahmin edilenin altında kaldığı belirlenmiştir (Bar-Or and Rowland 2004).

\section{Olgu Sunumu}

$\mathrm{Bu}$ makalede; hastanenin acil servisine 10.12.2005 tarihinde sabah saat 08.00'de karın ağrıs1, karında şişlik, iştahsızlık, halsizlik, öksürüğün eşlik ettiği tablo ile getirilen; yapılan tanı işlemleri, laboratuvar testleri ve kemik iliği aspirasyonu sonucu ALL (standart risk grubu) tanısı alan, 11 yaşındaki B olgu olarak sunulmuştur. B'nin tanı konulduktan sonra kemoterapi tedavisi almak üzere hastaneye tekrarlı yatışları yapılmıştır. B'ye tedavi olarak protokol I uygulanmış olup aldığı ilaçlar şu şekildedir: Prednizolon $60 \mathrm{mg} / \mathrm{m}^{2} /$ gün IV (3 doza bölünerek), vincristin $1,5 \mathrm{mg} / \mathrm{m}^{2} / \mathrm{doz} \mathrm{IV}$, asparaginaz $5000 \mathrm{UI} / \mathrm{m}^{2} / \mathrm{doz} 1$ saatlik infüzyon, metotreksat $12 \mathrm{mg}$.

Olgu B, 02.06.2006 tarihinde de ağrı, kas krampları, kas zayıflığı, ayak bileği hareket alanında azalma ve ateş şikayetleri ile çocuk hematoloji kliniğine yatırıldıktan sonra Fizik Tedavi ve Rehabilitasyon ekibinden konsültasyon istenmiş, yapılan fizik muayene ve tetkikler sonucu kas gücünün üç̧ün üstünde olduğu, kaslarda zayıflık ve ayak bileği hareket alanında azalma olduğu tespit edilmiştir. Bunun sonucu hastaya aktif ve pasif dorsifleksiyon alt ekstremite egzersizleri (ROM) ile yapılan fiziksel egzersiz programı önerilmiştir. Olgu B'nin taburculuk planında da ev egzersiz programı kapsamında aktif ROM (alt ekstremite), bacak kaslarını güçlendirme egzersizleri ve aerobik egzersizler (dayanıklılık aktiviteleri) önerilen komponentlerdir. Evde egzersiz programı hakkında, aileden ve çocuktan bilgilendirilmiş olur alınmış olup, bu kapsamda B ve ailesine ev egzersiz program kitapçığı verilerek, üç ay boyunca haftalık ev ziyaretleri ile fiziksel egzersizler desteklenmiştir.

B ve ailesine öğretilecek ev egzersiz programı şu şekilde planlanmıştır:

1) Aktif ROM Egzersizleri; haftada beş gün, günde üç kez, her tekrarda 20 kez yapılacak.

2) Bacak Kaslarını Güclendirme Egzersizleri; haftada üç gün, günde üç kez yapılacak.

3) Aerobik Egzersizler; Haftada üç gün, günde bir kez, yarım saat süre ile yapılacak.

Resimli ve yazılı egzersiz programı, B ve ailesine verilmiştir.

Marjory Gordon, sağliklı / hasta bireyden veri toplamayı standardize eden ve hemşirelik tanısını belirlemeyi kolaylaştıran “11 Fonksiyonel Sağlik Örüntüleri”ni geliştirmiştir (Birol 2002). B'nin sağlık öyküsü M. Gordon’un “11 Fonksiyonel Sağlık Örüntüleri”ne göre değerlendirilmiştir.

\section{B'nin Sağlık Öyküsü'nün Gordon'un Fonksiyonel Sağlık Örüntülerine Göre Değerlendirilmesi}

1. Sağlığın Algılanması: B ilk kez beş yaşında iken pnömoni nedeniyle hastaneye yatmış, burada akciğer biyopsisi yapılmış. Daha sonra da 10.12.2005 tarihinde karın ağrısı ve karında şişlik şikayetleri ile hastaneye başvurmuşlar. Bu yatışından sonra hastaneye tekrarlı olarak yatışları olmuş. Sağlik güvenceleri yok.

2. Beslenme Şekli ve Metabolik Durumu: Annesi, B'nin genelde iştahsız bir çocuk olduğunu ve özellikle bu hastalığından (ALL) sonra iştahının iyice azaldığını ifade ediyor. Kusması bir hafta önce bir-iki kez olmuş. 
3. Boşaltım Şekli: Defekasyonu günde bir kez ya da iki günde bir kez normal kıvamda imiş. Bazen kabız oluyormuş. İki yıl öncesine kadar geceleri altını sslatıyormuş.

4. Aktivite-Egzersiz Şekli: Annesi, önceleri aktif olarak öz bakım aktivitelerini yaptığını, hastalığından sonra B'nin çok değiştiğini, günlük yaşam aktivitelerini yerine getirmek istemediğini belirtiyor. Giysisini giyme, banyo yapma, tırnak bakımı gibi benzer aktiviteleri yerine getirmek istemiyor, annesinin yapmasını bekliyor. B tekrarlı hastaneye yatışlarından dolayı okula devam edemiyor.

5. Uyku-İstirahat Şekli: Akşam saat 22.00 gibi yatıp, sabah saat 07.00 'ye kadar uyuyormuş.

6. Bilişsel Algılama Şekli: B'de işitme güçlüğü, görme bozukluğu, dokunma ve hissetmede kayıp yok. Annesi, B'ye hastalığını söylemediklerini, vücudunda mikrop olduğu için hastalandığını söylediklerini ifade ediyor. Annenin, "oğlumun durumu ne olacak, tamamen düzelecek mi? Çocuğumun ciddi bir hastalığı olduğunun farkındayım, dünyam karardı, hiçbir şey yapmak istemiyorum" gibi ifadeleri olmaktadır. Aynı zamanda anne ile baba her işlemde sağlık ekibinin her söylediğini hemen yerine getiriyor.

7. Kendini Algılama, Kavrama Şekli: Y. Hanım, "çocuğumun önce boğazlarında bezeler oldu, bayă̆ı büyüktü. Daha sonra kasıklarında da oldu. Karnı şişmişti, ağrıları çok fazlaydı öyle ki ağrıdan duvarları yumrukluyordu. Çok korktuk." şeklinde çocuğunun durumunu ifade ediyor.

8. Rol-İlişki Şekli: Y. Hanım aile içi ilişkilerini şu sözlerle ifade ediyor; "eşim çok iyi birisidir, başka da akrabalardan kimseden fayda yok. Çoğu akrabalarımı İstanbul'da ama hiç faydaları yok, hiç arayıp sormazlar. Kayınvalidem beş yll önce evden kovdu. Eşim bizim her şeyimiz, bütün işleri o hallediyor, sürekli hastanede olduğu için de işten çıkarttılar. Bu nedenle maddi sıkıntı yaşlyoruz. Diğer çocuğuma, eşime zaman ayıramıyorum”.

B arkadaşlarının ve öğretmeninin ziyaretine gelmedikleri, telefonla da arayıp sormadıkları için üzüldüğünü belirtiyor.

9. Cinsellik ve Üreme: Y. Hanım, çocuğunun hastalığından dolayı eşiyle birbirlerine çok zaman ayıramadıklarını belirtiyor.

10. Başetme, Stresi Tolere Etme Şekli: Y. Hanım eşi ve iki çocuğu ile beraber oturuyor. Bütün akrabalarının İstanbul'da olmasına rağmen destek olmadıklarını ve "bir şeye ihtiyacınız var mı diye bile sormadılar, benim yanımda kimse olmadı̆̆ için eşim işten çıkarıldı" şeklinde sosyal destek kaynaklarının olmadığını ifade ediyor. B'de hastalandıktan sonra daha sinirli olduğunu ve en basit olaylara bile öfkelendiğini belirtiyor.

11. İnanç ve Değerler: Y. Hanım, çocuğunun bir an önce iyileşmesi için ona dua ettiklerini söylüyor. "Dini inançlarımız kuvvetli olduğu için oğlumun bu hastalığına hiç isyan etmedik, Allah'tan geldi, hep dua ediyoruz".

\section{Şuan uygulanan tedavi}

Bactrim 2x1 haftada 3 gün Duphalac 2x1

Prednol tb. $60 \mathrm{mg} /$ gün Cipram $20 \mathrm{mg} 1 \frac{1}{2}$ tb günde

Fizik Muayene Bulguları (02.06.2006) 
Vücut 1s1s1: $37.5-38.5{ }^{\circ} \mathrm{C}$, nabız: $82 / \mathrm{dk}$, kan basinc1: 110/80 $\mathrm{mmHg}$, solunum: 20/dk.(Oturarak)

\section{Tam Kan Sayımı Sonucları ( hasta dosya bilgileri ): ( 03.06.2006)}

$\begin{array}{ll}\text { Hb: } 7.4 \mathrm{~g} / \mathrm{dl} . & \text { SGOT: } 45 \mathrm{U} / \mathrm{L} \\ \text { WBC: } 15 \mathrm{~K} / \mathrm{uL} & \text { SGPT: } 48 \mathrm{U} / \mathrm{L} \\ \text { Hct: } 20.4 \mathrm{~g} / \mathrm{dl} . & \text { BUN: } 26 \mathrm{mg} / \mathrm{dL} . \\ \text { MCV: } 88.5 \mathrm{fL} . & \text { Kreatinin: } 0.42 \mathrm{mg} / \mathrm{dL} .\end{array}$

Genel Görünüm: Halsiz, endişeli görünüyor. Kıyafetleri düzgün ve temiz.

Deri: Renkte solukluk var. IV uygulamalara bağlı ekimozlar var.

Lenf Nodları: Tonsiller, sublingual lenf nodları mobil, büyüme var.

Baş: Simetrik doğal şeklinde. Başta kitle ve sertlik yok. Saçlarda dökülme var.

Boyun: Doğal görünümünde, hareket kısıtlılığı yok, tortikolis yok.

Gözler: Göz kapakları doğal. Akıntı, şaşılık, kızarıklık, kaşıntı yok. Pupiller izokorik, ışığa refleksi var.

Kulaklar: Kulak, kulak derisi doğal görünümde. Kulak yolu temiz görünüyor. Göz kulak çizgisi düşük değil.

Burun: Eksternal yapı doğal görünümde. Sinüzit, burun travması, burun tıkanıklığı yok.

Ăğız ve Boğaz: Dudak ve ağız mukozası normal. Sekresyon tükürük özelliğinde var. Ülserasyon, kanama yok. 1 eksik diş var.

Göğüs: Meme uçları doğal görünümde, akıntı yok. Raşitik rosary yok.

Akciğerler: Solunum sıkıntısı yok. Balgam çıkarmıyor. Öksürük yok. Raller kaba, solunum sayısı: 20/dk.

Kalp: Yetmezliği yok. Nabzı: 82/dk. Nabız ritmik, juguler, radial nabız palpe edilebiliyor.

Abdomen: Karın ağrısı ve karında şişlik var. Barsak sesleri 6/dk. Timpanik ses yok.

Genitaller: Testisler skrotumda, doğal. Sünnet olmuş. Üretral meatus glans ucunda, akıntı yok.

Anüs: Glutealler simetrik, perianal bölge doğal.

Sırt ve Ekstremiteler: Ekstremiteler simetrik görünümde, ayaklar eşit sıcaklıkta. DKÇ yok, halsizlik var.

Nörolojik: Bilinç açık, oryantasyon bozukluğu yok, duyusal kayıp yok, denge bozukluğu yok, kas güçsüzlüğü var, titreme, paralizi yok. 
Olgu B'nin Bakım Planı (Carpenito, 2005).

\begin{tabular}{|c|c|c|}
\hline $\begin{array}{l}\text { Hemşirelik } \\
\text { Tanısı }\end{array}$ & Planlama-Uygulama & Değerlendirme-Sonuç \\
\hline $\begin{array}{l}\text { 1)Anemiye } \\
\text { sekonder } \\
\text { sirkülasyonda } \\
\text { azalmaya bağlı } \\
\text { Vücut } \\
\text { Sıcaklığında } \\
\text { Değişim }\end{array}$ & 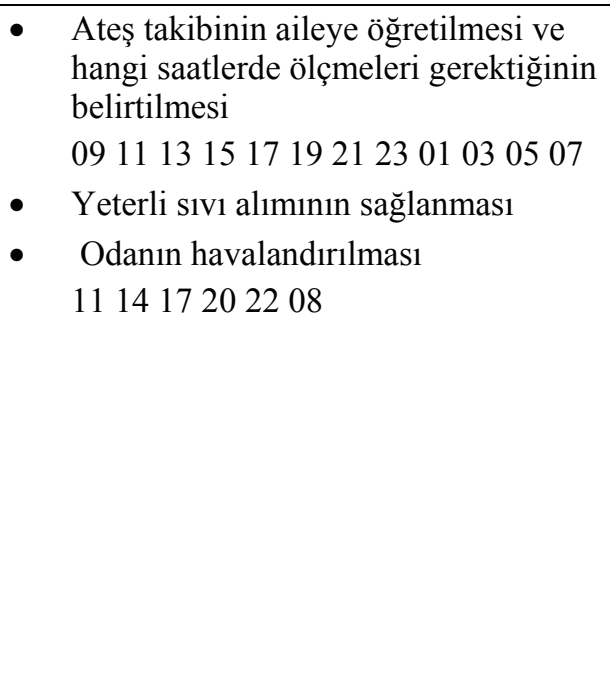 & $\begin{array}{ll}\text { 03.06.2006 } \\
\text { - } & \text { Ateş: } 37.5-38.5 \\
& { }^{\circ} \mathrm{C} \\
\text { - } & \text { Nabız: } 82 / \mathrm{dk} \\
\text { - } & \text { Solunum: } 20 / \mathrm{dk} \\
\text { - } & \text { Hb: } 7.4 \mathrm{~g} / \mathrm{dl} \\
\text { - } & \text { Bir tablet } \\
& \text { antipiretik verildi. } \\
& \text { Ateşi daha sonra } \\
& \text { 37.5 }{ }^{\circ} \mathrm{C}^{\prime} \text { ye düştü. } \\
& \text { 10.06.2006 } \\
\text { - } & \text { Ateşi yoktu. } \\
& \text { Odanın } \\
& \text { havalandırılması } \\
& \text { sağlandı. }\end{array}$ \\
\hline $\begin{array}{l}\text { 2) Kemoterapiye } \\
\text { sekonder; } \\
\text { görünümde } \\
\text { değişiklikler } \\
\text { olmasına bağlı } \\
\text { Beden Imgesinde } \\
\text { Bozulma }\end{array}$ & $\begin{array}{l}\text { - Kemoterapi ile ilgili değişimlerin (saç } \\
\text { kaybı) görüşülmesi } \\
\text { - Endişeleri, korkuları ve bu } \\
\text { değişimlerin yaşamı üzerine etkisini } \\
\text { nasıl algıladığının paylaşılması } \\
\text { - Tedaviden sonra saçların tekrar } \\
\text { çıkacağını, ancak renk ve kalitenin } \\
\text { değişebileceğinin açıklanması } \\
\text { - Çocuğun vücudundaki değissismlere } \\
\text { odaklaştırılması (örn. Küçükken } \\
\text { yapamadığın, şimdi yapabildiğin } \\
\text { neler var? }\end{array}$ & $\begin{array}{l}\text { 03.06.2006 } \\
\text { •B'nin. duygularını ve } \\
\text { özellikle kendisini nasıl } \\
\text { gördüğünü ifade etmesi } \\
\text { için cesaretlendirildi. } \\
\text { •Sağlık sorunu, tedavisi ve } \\
\text { prognozu hakkında soru } \\
\text { sorması için } \\
\text { cesaretlendirildi. } \\
\text { 10.06.2006 } \\
\text { - Sağlık sorunu, tedavisi } \\
\text { ve prognozu hakkında } \\
\text { konuşuldu. }\end{array}$ \\
\hline $\begin{array}{l}\text { 3) Hastalığın ve } \\
\text { tedavilerin } \\
\text { görünümü } \\
\text { etkilemesine ve } \\
\text { utanmaya bağlı } \\
\text { Sosyal İzolasyon }\end{array}$ & $\begin{array}{ll}\text { - } & \text { Neden olan, etkileyen faktörlerin } \\
\text { tanımlanması } \\
\text { - } & \text { Sosyal etkileşimlerinin geliştirilmesi } \\
\text { - } & \text { Bireysel ve destekleyici bir ilişki } \\
\text { sağlanması }\end{array}$ & 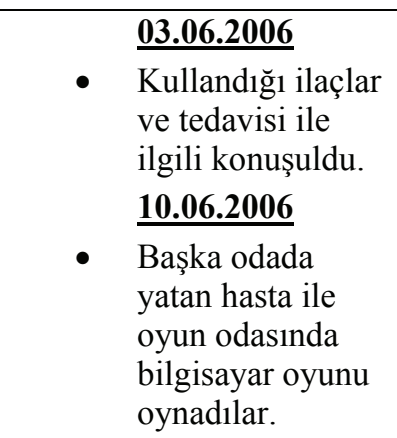 \\
\hline $\begin{array}{l}\text { 4) Hastalık } \\
\text { sürecine ve } \\
\text { tedavilere } \\
\text { sekonder; } \\
\text { anoreksiya ve } \\
\text { yorgunluğa bağlı } \\
\text { Beslenmede } \\
\text { Değişim: Yetersiz } \\
\text { Beslenme }\end{array}$ & $\begin{array}{ll}\text { - } & \text { Gerekli / yeterli olan günlük kalori } \\
\text { gereksinimlerinin tanımlanması } \\
\text { - } \quad \text { Günlük olarak vücut ağırlığının } \\
\text { tartılması } \\
\text { - } \quad \text { Yeterli beslenmenin öneminin } \\
\text { açıklanması } \\
\text { - } \quad \text { Başkaları ile birlikte yemek yemeye } \\
\text { teşvik edilmesi } \\
\text { - Yemek zamanına yakın, bulantı }\end{array}$ & 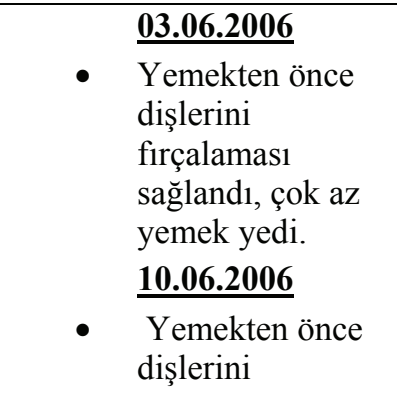 \\
\hline
\end{tabular}




\begin{tabular}{|c|c|c|}
\hline & $\begin{array}{l}\text { yaratan kokuların ortadan kaldırılması } \\
\text { ya da çevrenin düzenlenmesi } \\
\text { - Besinleri yemeden önce ve sonra iyi } \\
\text { bir ağı hijyeninin sağlanması }\end{array}$ & $\begin{array}{l}\text { firçalaması } \\
\text { sağlandı. Bulantı- } \\
\text { kusması olmadı. } \\
\text { Yemeğini yedi. } \\
\text { Vücut ağırlığı: } 27 \\
\text { kg. }\end{array}$ \\
\hline $\begin{array}{l}\text { 5) Tekrarlı } \\
\text { hospitalizasyona } \\
\text { sekonder; önemli } \\
\text { kişilerden ve } \\
\text { okuldan } \\
\text { ayrılmaya bağlı } \\
\text { Büyüme ve } \\
\text { Gelişmede } \\
\text { Değişim }\end{array}$ & $\begin{array}{l}\text { - } \quad \text { Arkadaşlarının ve öğretmeninin } \\
\text { telefonla aramaları ve ziyaret etmeleri } \\
\text { için teşvik edilmesi } \\
\text { B ile bakım ya da durum hakkındaki } \\
\text { duyguları, idealleri, endişeleri } \\
\text { konusunda sık sık konuşulması } \\
\text { - Okul arkadaşları ile etkileşimde } \\
\text { bulunması için desteklenmesi, } \\
\text { olanaklar sağlanması }\end{array}$ & $\begin{array}{ll}\mathbf{0 3 . 0 6 . 2 0 0 6} \\
\text { - } & \text { Okullar tatil } \\
& \text { olduğu için } \\
& \text { arkadaşları ve } \\
& \text { öğretmenine } \\
& \text { ulaşılamadı. } \\
& \mathbf{1 0 . 0 6 . 2 0 0 6} \\
\text { - } & \text { Okuldan çok } \\
& \text { sevdiği arkadaşı } \\
& \text { ziyaretine geldiği } \\
\text { için çok mutlu } \\
\text { oldu. }\end{array}$ \\
\hline $\begin{array}{l}\text { 6) Yorgunluk, } \\
\text { motivasyon } \\
\text { azalmasına ya da } \\
\text { kas güçsüzlüğüne } \\
\text { bağll Fiziksel } \\
\text { Mobilitede } \\
\text { Bozulma }\end{array}$ & 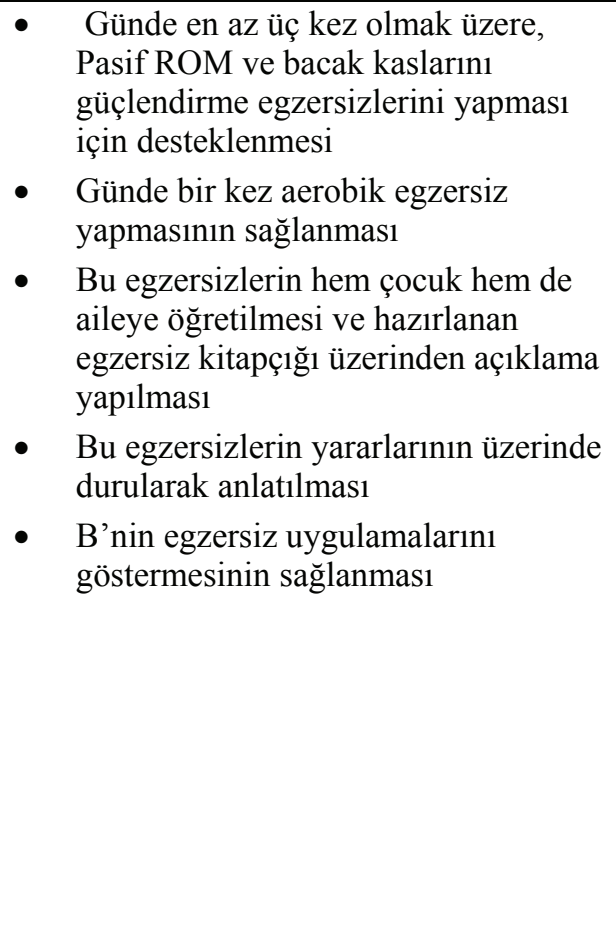 & 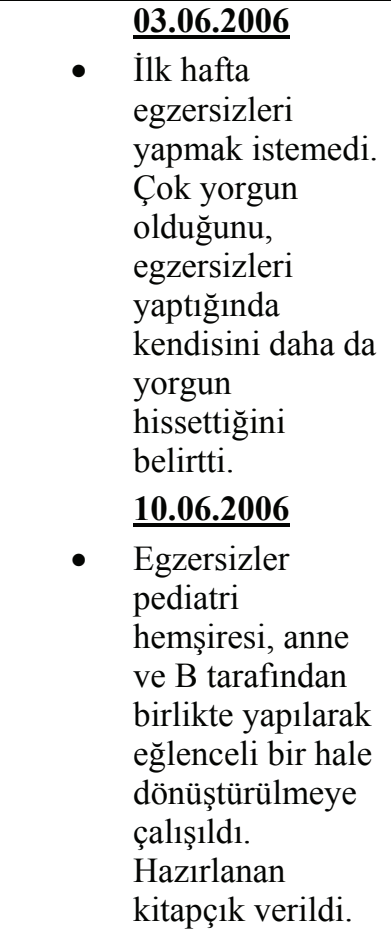 \\
\hline $\begin{array}{l}\text { 7) Kanser ve / } \\
\text { veya tedavinin } \\
\text { etkilerine bağlı } \\
\text { Aktivite } \\
\text { Intoleransl }\end{array}$ & $\begin{array}{l}\text { - Çocuğa yorgunluğunun beklenen bir } \\
\text { yan etki olduğunu, tedavi } \\
\text { sonlandıktan sonra 2-4 haftada yavaş } \\
\text { yavaş düzeleceğinin anlatılması } \\
\text { - } \quad \text { Aktivite düzeyinin belirlenmesi } \\
\text { - } \quad \text { B’ye yönelik yorucu aktivitelerin } \\
\text { yapılmamasına dikkat edilmesi } \\
\text { - } \quad \text { Enerji düzeyine uygun aktivitelerle } \\
\text { barışı olması için cesaretlendirilmesi } \\
\text { - Aktivitenin yavaş yavaş arttırılması }\end{array}$ & 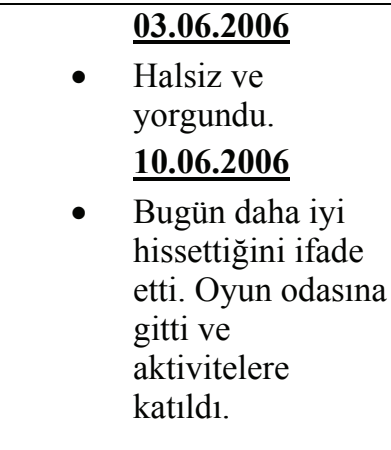 \\
\hline 8) Yorgunluğa, & - Her bir özbakım aktivitesine & 03.06.2006 \\
\hline
\end{tabular}




\begin{tabular}{|c|c|c|}
\hline $\begin{array}{l}\text { halsiz-zayıf } \\
\text { olmaya ve } \\
\text { depresyona bağlı } \\
\text { Özbakım Defisiti } \\
\text { Sendromu }\end{array}$ & $\begin{array}{l}\text { katılabilme yeteneğinin } \\
\text { değerlendirilmesi } \\
\text { - Özbakım defisitleri hakkındaki } \\
\text { duygularını ifade etmesi için } \\
\text { cesaretlendirilmesi } \\
\text { - } \quad \text { Kendi kendine karar vermesinin } \\
\text { geliştirilmesi } \\
\text { - Cipram } 20 \mathrm{mg} 1 / 2 \text { tb günde düzenli } \\
\text { olarak almasının sağlanması }\end{array}$ & $\begin{array}{l}\text { B’nin banyo, } \\
\text { tırnak kesme vb. } \\
\text { aktivitelerini } \\
\text { yapmak } \\
\text { istemediğini, } \\
\text { bunları annesinin } \\
\text { yapmasını istediği } \\
\text { görüldü. } \\
\text { 10.06.2006 } \\
\text { Kendisi } \\
\text { tırnaklarını } \\
\text { kesmek istediğini } \\
\text { söyledi. }\end{array}$ \\
\hline $\begin{array}{l}\text { 9)Tanı ve } \\
\text { tedavilerin } \\
\text { getirdiği strese, } \\
\text { rol } \\
\text { değişimlerindeki } \\
\text { sikıntılara bağlı } \\
\text { Aile İçi } \\
\text { Süreçlerde } \\
\text { Değişim }\end{array}$ & 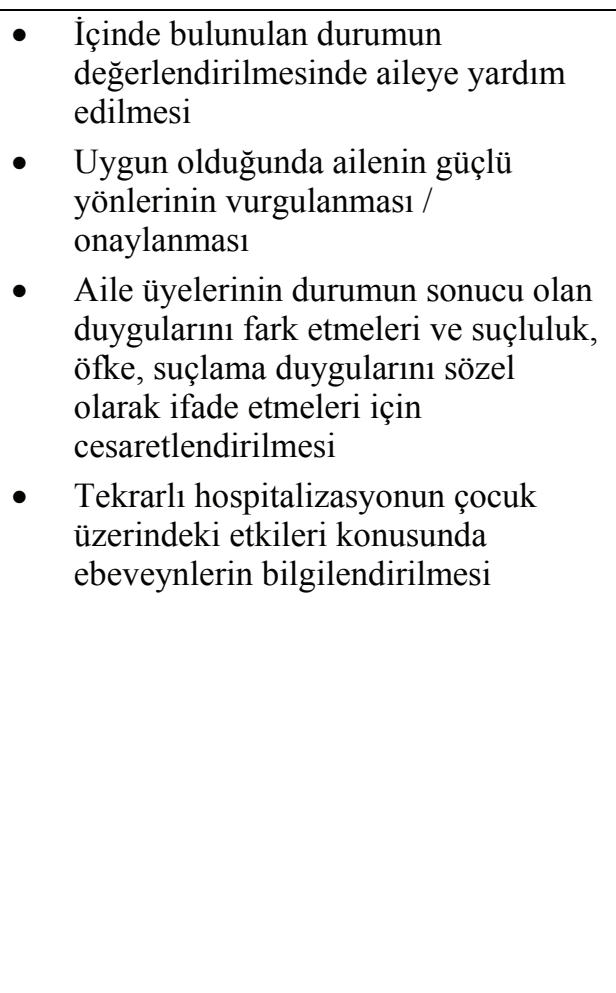 & 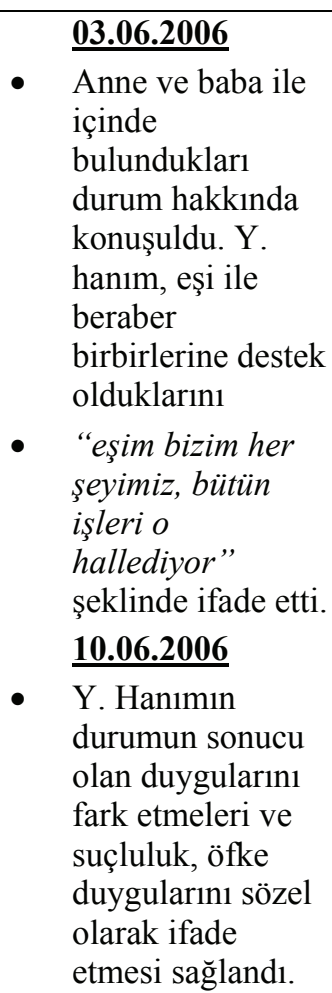 \\
\hline $\begin{array}{l}\text { 10) Kanserin uzun } \\
\text { süreli yönetimi } \\
\text { konusunda bilgi } \\
\text { eksikliğine bağlı } \\
\text { Sağliğı } \\
\text { Sürdürmede } \\
\text { Değişim }\end{array}$ & $\begin{array}{l}\text { - } \quad \text { Y. Hanım ve eşinin gereksindiği bilgi } \\
\text { ve teknik becerilerin tanımlanması } \\
\text { - } \quad \text { Mevcut bilgi ve beceri düzeyinin } \\
\text { tanımlanması } \\
\text { - } \quad \text { Sürekli izlem ve değerlendirmenin } \\
\text { yapılması }\end{array}$ & 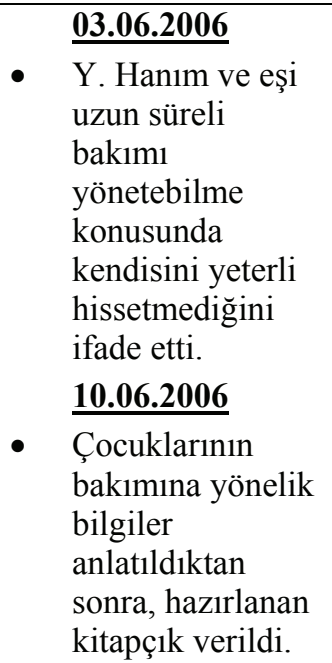 \\
\hline 11) Sitotoksik & ş takibinin yap1lması & 6.2006 \\
\hline
\end{tabular}




\begin{tabular}{|c|c|c|}
\hline $\begin{array}{l}\text { ajanlara ve } \\
\text { hastalık sürecine } \\
\text { sekonder, İmmün } \\
\text { sistemdeki } \\
\text { değişimlere bağlı } \\
\text { Enfeksiyon Riski }\end{array}$ & $\begin{array}{l}0911131519212301030507 \\
\text { - Enfeksiyon belirtilerinin gözlenmesi ve } \\
\text { aileye öğretilmesi (kızarıklı,, ödem, ateş, ağrı } \\
\text { vb.) } \\
\text { - Yapılan işlemlerin aseptik tekniklere uygun } \\
\text { yapılması ve ebeveynlerin bu konuda } \\
\text { bilinçlendirilmesi } \\
\text { • Eve gelen misafirlerin kontrolünün } \\
\text { sağlanması ve maske takmaları gerektiğinin } \\
\text { öneminin belirtilmesi }\end{array}$ & $\begin{array}{l}\text { - Ateş:37.5-38.5 }{ }^{\circ} \mathrm{C} \text {, } \\
\text { - WBC: } 15 \mathrm{~K} / \mathrm{uL} \text {, } \\
\mathrm{Hb}: 7.4 \mathrm{~g} / \mathrm{dl} \\
\text { • Y. Hanım, çocuğunun } \\
\text { hastalığından dolayı } \\
\text { arkadaş ve akrabalarla çok } \\
\text { fazla görüşmediklerini } \\
\text { ifade etti. } \\
\text { 10.06.2006 } \\
\text { •Ebeveynler ve B. ile } \\
\text { akrabaları, gelen } \\
\text { misafirlerle gerekli } \\
\text { önlemleri (maske gibi) } \\
\text { aldıktan sonra } \\
\text { görüşmelerinde bir sakınca } \\
\text { olmadığı, aksine } \\
\text { çocuklarının sosyalleşmesi } \\
\text { içinde önemli olduğu } \\
\text { vurgulandı. }\end{array}$ \\
\hline $\begin{array}{l}\text { 12) Hastalık } \\
\text { sürecine, } \\
\text { kemoterapiye, } \\
\text { oral hijyenin } \\
\text { yetersizliğine } \\
\text { bağlı Oral Müköz } \\
\text { Membranlarda } \\
\text { Değişim Riski }\end{array}$ & $\begin{array}{ll}\text { - } & \text { Oral mukozanın günlük olarak } \\
\text { değerlendirilmesi } \\
\text { - } & \text { Dişlerini yemeklerden sonra ve } \\
& \text { yatmadan önce yumuşak bir diş } \\
\text { firçası ile firçalamasının öneminin } \\
\text { açıklanması } \\
\text { - Periyodik olarak diş kontrollerinin } \\
\text { öneminin açıklanması }\end{array}$ & 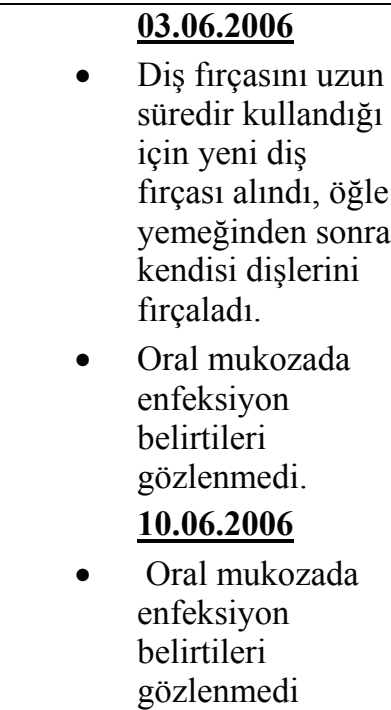 \\
\hline $\begin{array}{l}\text { 13) Ekonomik } \\
\text { yetersizliğe, } \\
\text { desteğin } \\
\text { olmamasına bağlı } \\
\text { Bakım Verici } \\
\text { Rolünde } \\
\text { Zorlanma }\end{array}$ & $\begin{array}{ll}\text { - } & \text { Bu duruma neden olan faktörlerin } \\
\text { değerlendirilmesi }\end{array}$ & 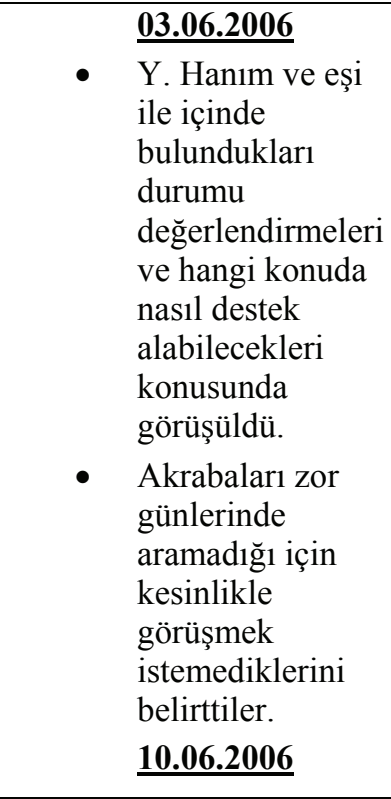 \\
\hline
\end{tabular}




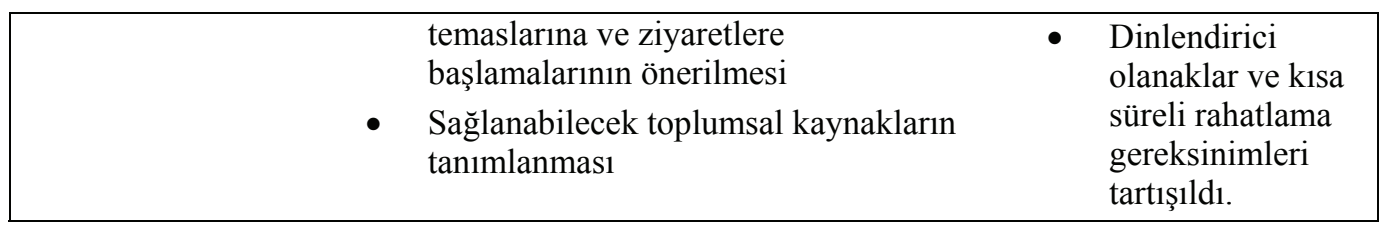

\section{Sonuç ve Öneriler}

Olgu B, 3 ay boyunca çocuk hemşiresi tarafindan yapılan haftalık ev ziyaretleri ile desteklenen fiziksel egzersiz sonucunda, ebeveynleri B'nin evde egzersizlerini düzenli olarak yaptığını, günlük aktivitelerini yerine getirmede şikâyetçi olmadığını ve moral olarak çok daha iyi olduğunu ifade etti. B'de yorgunluk ve halsizliğinin azaldığını, egzersizleri yaptığında kendisini daha iyi hissettiğini belirtti.

$\mathrm{Bu}$ amaçla, ülkemizde ALL'li çocuklarda zaman içerisinde oluşan fiziksel ve psikolojik değişiklikleri azaltmak, rehabilitasyon çalışmalarına kanıta dayalı bir perspektif geliştirerek hemşirelerce uygulanabilecek bir rehabilitasyon prosedürü oluşturulması amaçlandı. Aynı zamanda B'nin bakım gereksinimlerinin saptanması, bunlara yönelik hemşirelik bakım planının oluşturulmasında Gordon'un Fonksiyonel Sağlık Örüntüleri'nin yararlı ve etkin olduğu görüldü.

\section{KAYNAKLAR}

[1] Bar-Or O, Rowland TW. Physiologic and Perceptual Responses to Exercise in the Healthy Child In: Pediatric Exercises Medicine from Physiologic Principles to Health Care Application. 1 edition, Human Kinetics Publishers 2004; 3-321.

[2] Barr RD, Sala A. Osteonecrosis in children and adolescents with cancer. Pediatr Blood Cancer 2008; 50(2 Suppl):483-5.

[3] Bhatia S, Constine LS. Late morbidity after successful treatment of children with cancer. Cancer Journal 2009; May-Jun;15(3):174-80.

[4] Birol L. Hemşirelik Süreci. 5. baskı, Etki Matbaacılık Yayıncılık Ltd. Şti, İzmir, 2002.

[5] Carpenito LJ. Hemşirelik Tanıları El Kitabı. Çev. Editörü: Erdemir F., Nobel Tıp Kitabevleri, İstanbul, 2005.

[6] Edgar AB, Morris EM, Kelnar CJH, Wallace WHB. Long-term follow-up of survivors of childhood cancer. Endocr Dev, 2009; 15:159-80.

[7] Gocha VA, Chiarello LA, Lange BJ. Strength and functional mobility in children with acute lymphoblastic leukemia. Med Pediatr Oncol, 2003; 40:230-232.

[8] Hartman A, van den Bos C, Stijnen T, Pieters R. Decrease in motor performance with cancer is independent of the cumulative dose of vincristine. Cancer 2006; Feb 1; 106 (6): 1395-1401.

[9] Hartman A, van den Bos C, Stijnen T, Pieters R. Decrease in peripheral muscle strength and ankle dorsiflexion as long-term side effects of treatment for childhood cancer. Pediatr Blood Cancer 2008; Apr;50(4):833-7.

[10] Hockenberry-Eaton M, Wilson D, Winkelstein ML, Kline NE. Whaley \& Wong's nursing care of infants and children. Seven edition. Mosby, St. Louis, 2002; 1705-1736. 
[11] Mattano LA, Sather HN, Trigg ME, Nachman JB. Osteonecrosis as a complication of treating acute lymphoblastic leukemia in children: A report from the children's cancer group. Journal of Clinical Oncology 2000; 18 (18): 3262-3272.

[12] Neyzi O, Ertuğrul T. Pediatri. 3. baskı, Nobel Tıp Kitabevleri, Tayf Ofset, Yeni Güven Ciltevi, 2002; 1106-1113.

[13] Pui CH, Evans WE. Treatment of acute lymphoblastic leukemia. New England Journal of Medicine 2006; 354:166-178.

[14] Reinders-Messelink H, Schoemaker M, Snijders T, Göeken L, van Den Briel M, Bökkerink J, Kamps W. Motor performance of children during treatment for acute lymphoblastic leukemia. Medical and Pediatric Oncology 1999; 33 (6): 545-550.

[15] San Juan AF, Fleck SJ, Chamorro-Viña C, Maté-Muñoz JL, Moral S, Pérez M, Cardona C, Del Valle MF, Hernández M, Ramírez M, Madero L, Lucia A. Effects of an intrahospital exercise program intervention for children with leukemia. Med Sci Sports Exerc, 2007; Jan;39(1):13-21.

[16] San Juan AF, Chamorro-Viña C, Maté-Muñoz JL, Fernández del Valle M, Cardona C, Hernández M, Madero L, Pérez M, Ramírez M, Lucia A. Functional capacity of children with leukemia. Int J Sports Med, 2008; Feb;29(2):163-7.

[17] Shaw S. Endocrine late effects in survivors of pediatric brain tumors. J Pediatr Oncol Nurs, 2009; Sep-Oct;26(5):295-302.

[18] Smith MA, Gloeckler Ries LA, Gurney JG, Ross JA. Leukemia. http://seer.cancer.gov/publications/childhood/leukemia.pdf (Erişim Tarihi: 15.11.2011).

[19] White J, Flohr JA, Winter SS, Vener J, Feinauer LR, Ransdell LB. Potential benefits of physical activity for children with acute lymphoblastic leukemia. Pediatric Rehabilitation 2005; 8(1):5358.

[20] Wright MJ, Halton JM, Barr RD. Limitation of ankle range of motion in survivors of acute lymphoblastic leukemia: A cross-sectional study. Medical and Pediatric Oncology 1999; Apr; 32(4):279-82.

[21] Wright MJ, Hanna SE, Halton JM, Barr RD. Maintenance of ankle range of motion in children treated for acute lymphoblastic leukemia. Pediatr Phys Ther, 2003; Fall;15(3):146-52. 